\title{
SUSTAINABLE CONSUMPTION AND ETHICAL BEHAVIOR OF CONSUMERS IN THE FOOTWEAR INDUSTRY
}

\author{
ALEXANDRA LUCA, MARIA CARMEN LOGHIN \\ "Gheorghe Asachi” Technical University of Iasi, Faculty of Textile - Leather and Industrial \\ Management, 28 D. Mangeron, Iasi, Romania, alexandra.luca@tuiasi.ro; cloghin@tex.tuiasi.ro
}

\begin{abstract}
Traditionally shoes are made from leather and most of the worldwide population wear it, but there is a particular group of consumers, with an ethical behavior, who prefer shoes made from alternative materials. In our days, the main objective of the fashion industry (T\&C, footwear) is to reduce the intensive use of fossil energy, non-renewable raw material and decreasing of landfill waste. In past years, sustainable and ethical consumption has become a popular topic in industries, has gained increasing importance in wealthy countries all over the world. This paper presents some point of view about ethical footwear and the consumer behavior, it also provides a brief overview of global consumption of footwear, as starting point for a new approach of the supply chain of footwear industry. The objective of this paper is to present consumers perception and interests regarding ethical footwear and ethical brands. To reach the main objective of the article, the methodology of the research consists in a survey applied to a target group of Romanian people, men and women, with average to high incomes, interested in buying less but sustainable products.
\end{abstract}

Keywords: sustainable footwear, ethical consumer, sustainable consumption.

\section{INTRODUCTION}

In recent years, the fashion industry environmental impact is growing considering the use of cotton, natural leather, wool and synthetics. It is known that leather production requires high water consumption and chemicals (used in leather tanning like chromium) with a negative impact on the environment. The production process, especially tanning, drying, dyeing and finishing uses chemicals and generate a high environmental impact (Caniato et al., 2011). A lot of fashion companies have requested assistance from foreign partners to produce their products, in order to subcontract some activities like cutting, sewing, dyeing to different firms across the world; leading to an improved supply chain (Kleindorfer et al., 2005; Elkington, 1994; Zhu et al., 2008). Therefor EU footwear industry is trying to cut costs by working together with vendors in low cost countries.

\section{Global Footwear Market}

In 2014, the worldwide production of footwear, according to APICCAPS, has increased from 2013 by $8 \%$ and reached 24.3 billion pairs. Asia accounts for $88 \%$ of global production, followed by South America 5\%, Africa 3\% and North America 2\%. China remains a leader among footwear producing countries. The European footwear production shows a slightly decrease in the production, currently $3 \%$.

In 2014 Asia was the biggest consumer of footwear, especially China is the largest market for footwear with 3.65 billion pairs followed by European Union with 2.77 billion pairs and United States with 2.29 billion pairs. US consumers bought per capita in 2013, $71 \frac{1}{2}$ pairs of shoes, $98 \%$ of shoes sold are imported from China, according to a report by the American Apparel \& Footwear Association (AAFA). The highest consumption of footwear in Europe is United Kingdom with 523 billion pairs, and figure 1 presents the leading 10 global footwear consumers in 2014 , by country. 


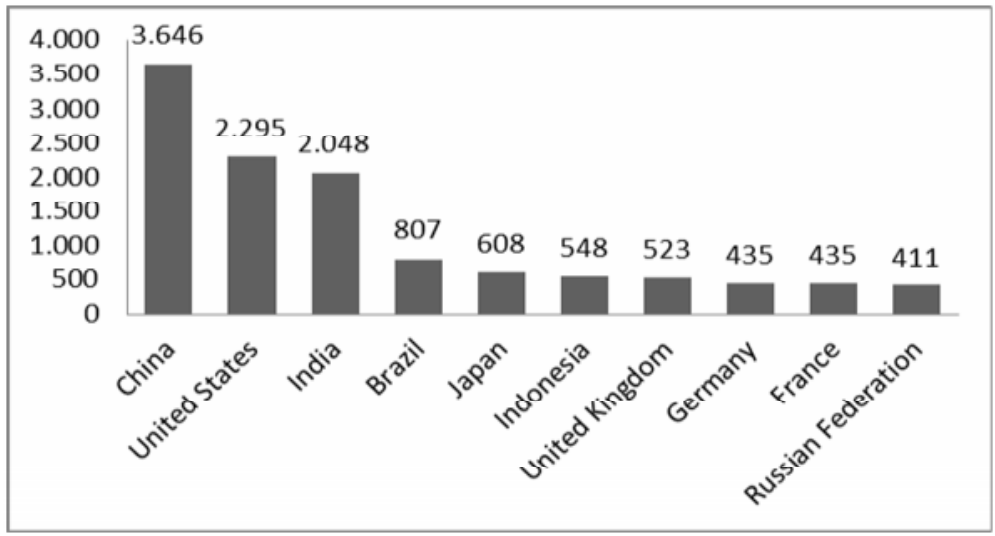

Figure 1. Top 10 of 2014 global footwear consumers (in number of pairs) Source: World Footwear Yearbook 2015

\section{European Footwear Market}

\section{Production}

In 2014 the most important producer is Italy (Figure 2) accounted for $50 \%$ of total European production, followed by Spain (13\%), Portugal (12\%) and Romania (8\%). The total value of EU production of footwear has increased from $€ 14.1$ billion in 2010 up to $€ 17.4$ billion in 2014 .

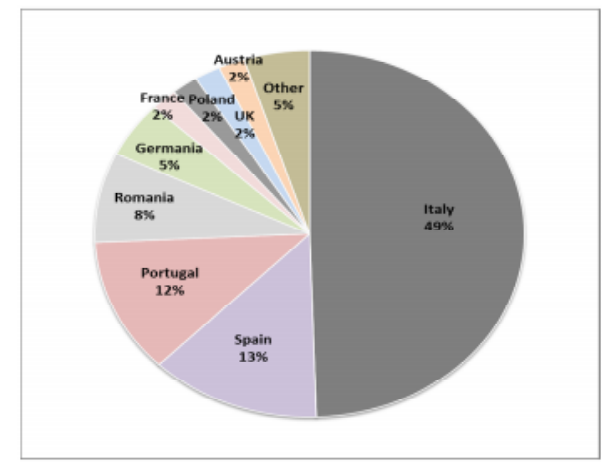

Figure 2. European production of footwear in 2014

Source: Eurostat, Prodcom, 2015

The EU footwear production industry focuses on adding value to products improving the design, comfort, quality, materials in order to respect the environmental rules. The EU has always been a significant provider of high quality footwear to the world market. But, the mass production was outsourced in Asia; currently 6 out of 10 pairs of shoes worldwide are produced in China.

Romania is an important player in this market and even feared by competitors since Romanian footwear reached $14 \%$ of total trade value. 
ICAMS 2016 $-6^{\text {th }}$ International Conference on Advanced Materials and Systems

\section{Consumption}

Between 2010 and 2014 the European consumption of footwear had a compound annual growth rate of $2.9 \%$, reaching $€ 23.5$ billion in 2014 .

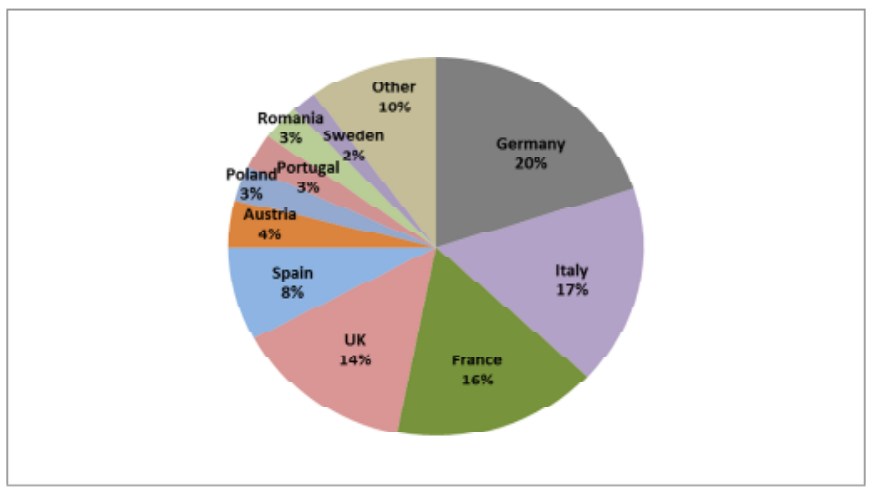

Figure 3. EU footwear consumption in 2014

Source: Eurostat / ProdCom, 2015

The consumption of footwear increased between 2010 and 2014 in developed countries (Denmark $+7.6 \%$, Austria 6.9\%) and East European countries (Poland $+6.6 \%$, Estonia $+19 \%)$. This growth in consumption of footwear is explained by population growth; market demand is growing; fashion changes very often. Another fact is that consumers are more informed about the international brands which means a developed and efficient supply chain.

In the same period of time southern European markets shows a decrease in consumption of footwear, for example Greece (-6\%), Spain (-2.1\%), Cyprus (-6.3\%).

In 2014, over 52\% of consumers bought footwear made of leather (Figure 4) and the EU demand for textile footwear increased between 2010 and 2014 with $7.7 \%$ per year; meaning that consumers are interested in other materials than leather.

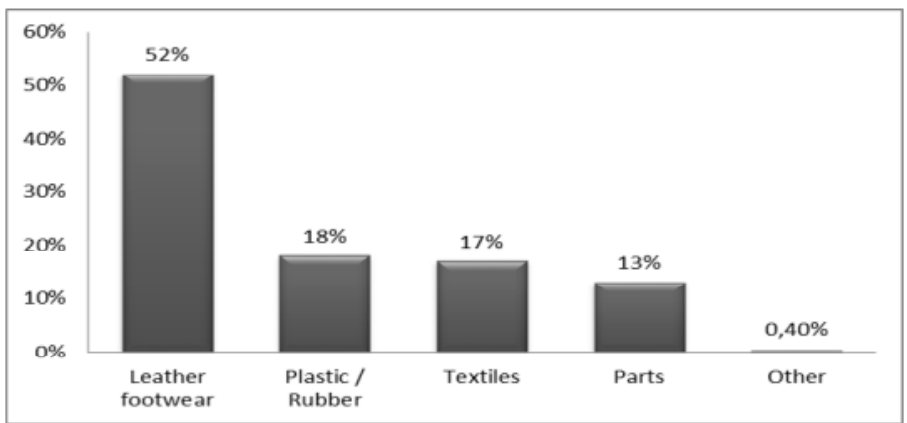

Figure 4. European footwear consumption by consumers choices 


\section{Sustainable Consumption \& Ethical Consumer}

The concept of sustainable consumption was defined for the first time in 1994 by the Oslo Symposium as "the use of services and related products, which respond to basic needs and bring a better quality of life while minimizing the use of natural resources and toxic materials as well as the emissions of waste and pollutants over the life cycle of the service or product so as not to jeopardize the needs of further generations".

Adopting the sustainable consumption patterns is the responsibility of all the people, but for this, population should be educated, motivated to change their habits and adopt a sustainable lifestyle.

An ethical consumer is a person who buy products which are eco - friendly from ethical companies, it is also aware about the negative impact on the environment of the production process, consumption and disposal. Generally consumers are influenced by many factors (Hoyer, 2012) divided in: demographic aspects such as gender, age, income, occupation, lifestyle, family size, religion, nationality; and social, personal, cultural aspects.

This paper investigates the awareness of the Romanian consumers towards ethical footwear. In Romania, consumers awareness is increasing in the last years, they are having various requirements and are influenced by several aspects but the footwear industry is responding with a wide range of products.

\section{RESEARCH METHODOLOGY}

The method used was primary market research, a survey was created. The questionnaire contain 15 items exploring the quantity of shoe purchases, the kind of raw materials they are made from, brand, price, interest of consumers about sustainable footwear, buying behavior of consumers of footwear, followed by four questions regarding demographic aspects such as gender, age, education level and income level of the respondent. Using two modes of administration: paper - and - pencil and computerized administration.

In the questionnaire closed-ended questions were used, as well a Likert scale for most of the questions, which is commonly used in marketing and can easily measure the satisfaction level of consumers.

The sample consists of consumers who participate at a footwear fair in Iasi. The clients were asked to be part of the study and complete the survey. The sample consists of 40 individuals, as shown in Figures 5-8.

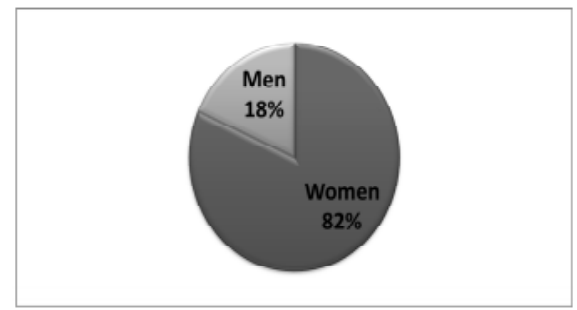

Figure 5. Sample structure by gender

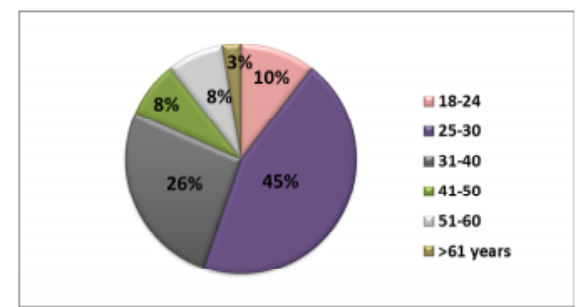

Figure 6. Sample structure by age 
ICAMS 2016 $-6^{\text {th }}$ International Conference on Advanced Materials and Systems

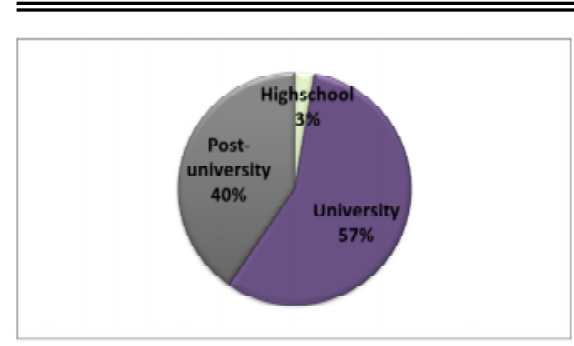

Figure 7. Sample structure by education level

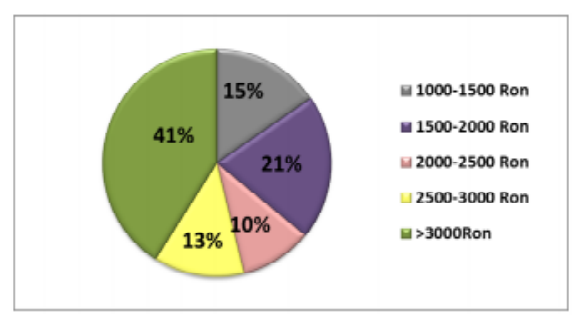

Figure 8. Sample structure by income level

\section{RESULTS AND DISCUSSIONS}

The data was collected in real time and analyzed using Google Forms.

The first questions in the questionnaire were designed to investigate the buying behavior of consumers and which aspects they follow in this purchase.

The first part of the survey aimed to investigate the amount of shoes bought in the last 3-6 months, the kind of raw materials they were made from, the brand, price and the place where they bought, and what are the reasons for this purchase.

In terms of quantity of shoes bought in the last 3-6 months $51.3 \%$ of respondents bought 2 pairs, followed by $33.3 \%$ with $3-4$ pairs and $15.4 \%$ purchased over 4 pairs of shoes. As we can see more than half of respondents bought 2 pairs of shoes and this is a positive fact if we refer to environmental aspects, however for the industry and economy is not;

More than half of respondents (56.4\%) prefer leather shoes because of their quality and lastingness; leather shoes are the most common in stores. 35.9\% of interviewed are wearing shoes made from leather and textiles, such as snickers, and this is happening because $45 \%$ of the respondents have between $25-30$ years old. Even so consumers (7.7\% of respondents) turned their attention to friendly leather shoes such as fake leather made from a polyurethane synthetic microfiber or vegetable-tanned leather.

For this purchase, $43.6 \%$ of respondents bought form the mall, followed by $23.1 \%$ bought online, $20.5 \%$ from outlet and second hand stores and $12.5 \%$ from local producers. Buying footwear from the mall is the simplest option, but if consumers were more informed about the local producers perhaps they could have more options.

The second part of the survey is to find out the interest of consumers regarding sustainable footwear. The results reveal that $71.8 \%$ of respondents heard about sustainable footwear but the knowledge and information they have are limited.

Most of respondents do not trust in these shoes and their characteristics because they do not have enough information (65\%), the prices are higher than regular shoes (80\%) and the design / style is different and more daring (52\%).

When they were asked about the reasons of buying sustainable footwear most respondents said that the most important factor is that shoes are eco - friendly $(85 \%)$, followed by the treatment of employees (70\%) and the manufacturing process affects less the environment $(67.5 \%)$.

Only $43.6 \%$ of respondents believe that can help to protect the environment using / buying shoes from second hand stores for several reasons: saving resources for their manufacture, reducing waste and supporting local businesses. 


\section{CONCLUSIONS}

This paper investigates the awareness of the Romanian consumers towards ethical footwear. From the research conducted it can be seen that consumers are interested for ethical footwear, but the knowledge and information they have are limited.

It is not necessary to purchase eco footwear in order to be an ethical / conscious consumer. Buying footwear from ethical brands it is the aim but it is enough if the consumers would be more educated and informed about the consequences of higher consumption of footwear.

In the end, clients have a strong aspiration to buy more consciously and the key is to continue to educate them in order to become a conscious consumers.

\section{REFERENCES}

AAFA (American Apparel \& Footwear Association) reports, https://www.wewear.org/apparelstats-2014-andshoestats-2014-reports.

APICCAPS, http://www.apiccaps.pt/web/guest.

Caniato, F., Cardi, M., Crippa, L. and Moretto, A. (2011), "Environmental sustainability in fashion supply chains: An exploratory case based research", International Journal of Production Economics, 135, 659670 .

Deselnicu, D.C., Vasilescu, A.M., Purcarea, A.A. and Militaru, G. (2014), "Sustainable consumption and production in the footwear sector", Leather and Footwear Journal, 14(3), 159-180.

Elkington, J. (1994), "Towards the Sustainable Corporations: win-win-win business strategies for sustainable development”, California Management Review, 36(2), 90-100.

Eurostat, http://ec.europa.eu/eurostat.

Hoyer, W.D., Macinnis, D.J. and Pieters, R. (2012), Consumer Behaviour, Sixth edition, South-Western, USA.

Kleindorfer, P.R., Singhal, K. and Wassenhove, L.N.V. (2005), "Sustainable operation management", Production and Operations Management, 14(4), 482-492.

Norwegian Ministry of Environment (1994), Oslo Symposium, http://www.unep.org/resourceefficiency/ Home/WhatisSCP/tabid/105574/Default.aspx.

World Footwear Yearbook (2015), http://www.worldfootwear.com/yearbook.asp?s=1\&ss=91\&year_sel=2015.

Zhu, Q., Sarkis, J. and Lai, K.H. (2008), "Confirmation of a measurement model for green supply chain management practices implementation", International Journal of Production Economics, 111(2), 261273. 